medRxiv preprint doi: https://doi.org/10.1101/2020.07.15.20154682; this version posted July 16, 2020. The copyright holder for this preprint

(which was not certified by peer review) is the author/funder, who has granted medRxiv a license to display the preprint in perpetuity.

All rights reserved. No reuse allowed without permission.

Corresponding author:

18

19 Mark H. Ebell MD, MS

20125 BS Miller Hall

21 UGA Health Sciences Campus

22 Athens, GA 30602

23 ebell@uga.edu

24 706-247-4953

25

\section{Word counts}

27 Text: 1197 words

28 Abstract: 250 words

29 Tables: 1
Mark H. Ebell MD, MS (1)

Laura Bierema, EdD (2)

Lauren Haines (1)

\author{
Laura Bierema, EdD
}

Lauren Haines (1) \title{
returning to campus in the era of COVID-19 \\ Graduate students significantly more concerned than undergraduates about
}


medRxiv preprint doi: https://doi.org/10.1101/2020.07.15.20154682; this version posted July 16, 2020. The copyright holder for this preprint (which was not certified by peer review) is the author/funder, who has granted medRxiv a license to display the preprint in perpetuity.

All rights reserved. No reuse allowed without permission.

\section{Abstract}

\section{Introduction}

32 As students return to colleges and universities in the fall of 2020 , it is important to understand

33 their perception of risk and their desire for in person versus online learning, which may differ

34 between undergraduate and graduate students.

\section{Methods}

36 We anonymously surveyed 212 undergraduate and 134 graduate students in the College of

37 Public Health, and 94 graduate students in the College of Education in late June, 2020. We

38 asked them Likert style questions regarding their comfort returning to campus and their

39 preferred learning strategies once back. We compared "Strongly agree/Agree" with

40 "Neutral/Disagree/Strongly disagree" using a chi-square test.

\section{Results}

42 Graduate students were significantly less likely to look forward to being on campus (38.3\%

43 doctoral vs $40.6 \%$ master's vs $77.7 \%$ undergraduate, $p<0.001$ ), more likely to perceive

44 themselves as high risk (43.3\% doctoral vs $40.0 \%$ masters vs $17.5 \%$ undergraduate, $p<0.001)$,

45 and were more likely to prefer all classwork online (66.7\% doctoral vs $44.6 \%$ master's vs $20.8 \%$

46 undergraduate, $p<0.001)$. Graduate students were also less likely to prefer to be in the

47 classroom as much as possible in the fall (59.2\% doctoral vs $67.7 \%$ master's vs $74.5 \%$

48 undergraduate, $\mathrm{p}<0.001)$. Most were not concerned about their ability to conduct research.

49 Students generally supported wearing of facemasks indoors.

\section{Conclusions}

51 There are important differences in perception of risk and desire for online versus in-person

52 learning between undergraduate and graduate students. Faculty and administrators must

53 acknowledge and address these differences as they prepare for return to campus in the fall. 
medRxiv preprint doi: https://doi.org/10.1101/2020.07.15.20154682; this version posted July 16, 2020. The copyright holder for this preprint (which was not certified by peer review) is the author/funder, who has granted medRxiv a license to display the preprint in perpetuity.

All rights reserved. No reuse allowed without permission.

\section{Introduction}

56 The COVID-19 pandemic caused by the SARS-CoV-2 virus has created a worldwide health

57 crisis. There have been over 10 million confirmed cases and over 500,000 deaths worldwide, ${ }^{1}$

58 with an estimated 10 undetected cases per confirmed case. ${ }^{2}$ As students return to campus in

59 the fall, it is important to understand their concerns and willingness to engage in usual

60 classroom activities. We hypothesize that undergraduate and graduate students may have

61 different attitudes towards returning to campus based on differences in age, attitudes toward

62 risk-taking behavior, likelihood of comorbid illness, and different living circumstances. . $^{3,4}$

63 Therefore, we anonymously surveyed students at the University of Georgia in the College of

64 Public Health and the College of Education with regards to their attitudes toward returning to

65 campus and their preferred learning environment.

\section{Methods}

68 The purpose of this survey was initially to provide guidance to faculty and administrators in the

69 College of Public Health at the University of Georgia regarding re-opening in the fall in the face

70 of the COVID-19 pandemic. The survey was shared with faculty in the College of Education who

71 had similar concerns. Once the survey results were examined, it was clear that they might be of

72 interest to the larger academic community and the decision was made to publish the results.

73 The survey was performed online in late June, 2020.

75 The questions used a Likert style format, with options of "Strongly disagree", "Strongly agree",

76 "Neutral", "Agree", and "Strongly agree". After surveing students in the Department of

77 Epidemiology and Biostatistics, the survey was slightly adapted by leadership of the College of

78 Public Health (the question "I am comfortable with a requirement that students and faculty wear

79 masks in indoor spaces and during classes" was changed to "Strongly encouraging student to

80 wear face masks while indoors or during face-to-face lectures is a good idea", and the question 
medRxiv preprint doi: https://doi.org/10.1101/2020.07.15.20154682; this version posted July 16, 2020. The copyright holder for this preprint (which was not certified by peer review) is the author/funder, who has granted medRxiv a license to display the preprint in perpetuity.

All rights reserved. No reuse allowed without permission.

81 "I prefer not to wear face masks while indoors or during face-to-face lectures" was added).

82 Students in the other departments of the College of Public Health were then invited to

83 participate, including graduate students and undergraduates. Finally, the survey was adapted

84 by faculty in the program of Learning Leadership and Organizational Development in the

85 College of Education and sent to their graduate students. They changed response categories

86 from 5 to 4 , eliminating "Neutral".

88 For analysis, categories were collapsed to "Strongly agree or agree" versus "Neutral, disagree, 89 or strongly disagree". The chi-square test was used to evaluate statistical significance. Because

90 the surveys were originally done to guide policy and not as research, the Human Subjects

91 committee designated this as not human subjects research.

\section{Results}

94 The survey was completed by 346 graduate and undergraduate students in the College of

95 Public Health and 94 students in the College of Education. Among the College of Education 96 students, all in the Department of Lifelong Education Administration and Planning, 79 were

97 pursuing a doctoral degree and 15 a Master's degree. Of the College of Public health students,

9870 were pursuing a doctoral degree, 64 a Master's degree, and 212 were undergraduates in

99 Health Promotion and Behavior or Environmental Health Sciences.

102 Graduate students were significantly more cautious regarding the return to campus. They were

103 less likely to agree with the statement that they were looking forward to being on campus

104 (38.3\% doctoral vs 40.6\% master's vs $77.7 \%$ undergraduate, $p<0.001)$, and more likely to 105 perceive themselves as being high risk for serious illness (43.3\% doctoral vs $40.0 \%$ masters vs $10617.5 \%$ undergraduate, $p<0.001)$. They were also more likely to agree that they preferred to 
medRxiv preprint doi: https://doi.org/10.1101/2020.07.15.20154682; this version posted July 16, 2020. The copyright holder for this preprint (which was not certified by peer review) is the author/funder, who has granted medRxiv a license to display the preprint in perpetuity.

All rights reserved. No reuse allowed without permission.

107 have all lectures and classwork online in the fall $(66.7 \%$ doctoral vs $44.6 \%$ master's vs $20.8 \%$

108 undergraduate, $p<0.001$ ), and less likely to prefer to be in the classroom as much as possible

109 in the fall $(59.2 \%$ doctoral vs $67.7 \%$ master's vs $74.5 \%$ undergraduate, $p<0.001)$. Just over

110 one-third of public health students were concerned about their ability to conduct research and

111 this did not differ by student category. Students generally supported wearing of facemasks while

112 indoors.

114 Conversely, undergraduate students had the lowest percentages for agreeing they were

115 concerned about acquiring COVID-19 upon return, for agreeing they wanted all classwork online

116 this fall, and for agreeing they were apprehensive about coming back to campus. Responses of

117 graduate students in the College of Education were compared with graduate students in the

118 College of Public Health. Students in the College of Public Health were slightly less likely to

119 favor a requirement to wear masks (74\% vs $88 \%, p=0.03)$. Otherwise there were no significant

120 differences in responses to the other questions.

\section{Discussion}

123 As students, faculty, staff, and administrators contemplate the return to campus this fall in the

124 face of COVID-19, each group is assessing their comfort with in-person teaching and on

125 campus meetings. In our survey, we found that students should not be treated as a monolithic

126 group, and that graduate students were much more concerned about their risk of acquiring

127 infection and significantly more comfortable with the idea of online instruction than

128 undergraduates.

130 The disparity between undergraduate and graduate perspectives about on campus instruction

131 and activities suggests that typical "Return to Campus Guidelines" do not cater to graduate

132 student concerns. This survey is critical to understanding that diverse student groups have 
medRxiv preprint doi: https://doi.org/10.1101/2020.07.15.20154682; this version posted July 16, 2020. The copyright holder for this preprint (which was not certified by peer review) is the author/funder, who has granted medRxiv a license to display the preprint in perpetuity.

All rights reserved. No reuse allowed without permission.

133 differing perspectives of risk. Given these range of perspectives regarding health and safety,

134 universities should provide more latitude in how courses and meetings will be conducted in light

135 of concerns for safety.

137 In 2018 there were approximately 1.8 million graduate students in the United States, of whom

$13857 \%$ were enrolled full-time with the largest enrollments in education, business, and health

139 sciences. ${ }^{5}$ These fields also have the largest proportions of part-time graduate students who

140 likely manage employment and dependent care in addition to graduate school. Notably, $57 \%$ of

141 graduate students are women, ${ }^{6}$ who usually bear the burden of domestic tasks and dependent

142 care. Further, research on homeschooling during the pandemic shows it is being handled

143 disproportionately by women, ${ }^{7}$ and longitudinal data show working mothers shoulder the bulk of

144 childcare and housework without reductions in work hours of more than 2 hours per day as

145 compared to 40 minutes for men. ${ }^{8}$

147 The average age of graduate students in the United States is approximately 33 years old, ${ }^{4}$ a

148 figure that has remained static over the years, with $22 \%$ of all graduate students over the age of

14940 years. ${ }^{9}$ Only $48 \%$ of graduate students are unmarried with no dependents, ${ }^{4}$ suggesting that

150 over half of graduate students tend to have more adult-like responsibilities than undergraduates

151 such as employment and dependent care, potentially putting graduate students at higher risk of

152 exposing family members and work colleagues to COVID-19 if they are attending courses on

153 campus.

154

155 Conclusions

156 It is important for university programs to take an evidence-based and flexible approach to the

157 return to campus, one that addresses the differing concerns of graduate and undergraduate

158 students. This is especially important in health and leadership professions where students are 
medRxiv preprint doi: https://doi.org/10.1101/2020.07.15.20154682; this version posted July 16, 2020. The copyright holder for this preprint (which was not certified by peer review) is the author/funder, who has granted medRxiv a license to display the preprint in perpetuity.

All rights reserved. No reuse allowed without permission.

159 learning how critical decisions affect the health and wellbeing of organizations and communities.

160 Administrators are advocating a "HyFlex" approach to instruction. We advocate that university

161 administrators should adopt a similarly flexible approach that emboldens faculty and students to

162 make decisions about pedagogy that reflect their personal risk factors, concerns, and goals.

163

164 Funding

165 This study was not externally funded.

166

\section{Acknowledgements}

168 The authors thank the students in the University of Georgia's Colleges of Public Health and

169 Education for their time spent completing this survey.

170

171 
medRxiv preprint doi: https://doi.org/10.1101/2020.07.15.20154682; this version posted July 16, 2020. The copyright holder for this preprint (which was not certified by peer review) is the author/funder, who has granted medRxiv a license to display the preprint in perpetuity.

\section{References}

173 1. Johns Hopkins COVID-19 Dashboard. https://coronavirus.jhu.edu/map.html. Accessed $174 \quad$ June 27, 2020.

175 2. Stringhini S, Wisniak A, Piumatti G, et al. Seroprevalence of anti-SARS-CoV-2 IgG 176 antibodies in Geneva, Switzerland (SEROCoV-POP): a population-based study. Lancet. 177 2020. doi:10.1016/s0140-6736(20)31304-0

178 3. Romer D. Adolescent risk taking, impulsivity, and brain development: Implications for 179 prevention. Dev Psychobiol. 2010. doi:10.1002/dev.20442

180 4. NCES. National Postsecondary Student Aid Study National Postsecondary Student Aid Study (NPSAS). In: NCES HANDBOOK OF SURVEY METHODS. ; 2017.

182 5. Okahana H, Zhou E. Graduate Enrollment and Degrees: 2007-2017. Washington, DC Counc Grad Sch. 2018.

6. Choy SP, Cataldi EF, National Center for Education Statistics (ED) DC. W, MPR Associates CA. B. Student Financing of Graduate and First-Professional Education: 2003-04. Profiles of Students in Selected Degree Programs and Part-Time Students. Statistical Analysis Report. NCES 2006-185.; 2006.

7. Miller CC. Nearly Half of Men Say They Do Most of the Home Schooling. 3 Percent of Women Agree. The New York Times. https://www.nytimes.com/2020/05/06/upshot/pandemic-chores-homeschooling191 gender.html.

192 8. Yavorsky JE, Kamp Dush CM, Schoppe-Sullivan SJ. The Production of Inequality: The Gender Division of Labor Across the Transition to Parenthood. J Marriage Fam. 2015. doi:10.1111/jomf.12189

195 9. Bell NE. Council of Graduate Schools (2009). Research report: Data Sources: Non196 Traditional Students in Graduate Education. 197 https://cgsnet.org/ckfinder/userfiles/files/DataSources_2009_12.pdf. Accessed July 14, 
medRxiv preprint doi: https://doi.org/10.1101/2020.07.15.20154682; this version posted July 16, 2020. The copyright holder for this preprint (which was not certified by peer review) is the author/funder, who has granted medRxiv a license to display the preprint in perpetuity.

All rights reserved. No reuse allowed without permission. 
medRxiv preprint doi: https://doi.org/10.1101/2020.07.15.20154682; this version posted July 16, 2020. The copyright holder for this preprint (which was not certified by peer review) is the author/funder, who has granted medRxiv a license to display the preprint in perpetuity.

201 Table 1. were less likely to want to be on campus

202

\begin{tabular}{|c|c|c|c|c|}
\hline Question & Undergrad & Master's & Doctoral & p \\
\hline $\begin{array}{l}\text { I am looking forward to being on campus in } \\
\text { the fall }\end{array}$ & $n=211$ & $\mathrm{n}=64$ & $n=141$ & \\
\hline Strongly agree or agree & $77.7 \%$ & $40.6 \%$ & $38.3 \%$ & $\mathrm{p}<.001$ \\
\hline Neutral, disagree, or strongly disagree & $22.3 \%$ & $59.4 \%$ & $61.7 \%$ & \\
\hline $\begin{array}{l}\text { I am concerned about acquiring the COVID- } \\
19 \text { infection after returning to campus }\end{array}$ & $n=212$ & $\mathrm{n}=65$ & $n=141$ & \\
\hline Strongly agree or agree & $71.2 \%$ & $78.5 \%$ & $83.7 \%$ & $\mathrm{p}=.024$ \\
\hline Neutral, disagree, or strongly disagree & $28.8 \%$ & $21.5 \%$ & $16.3 \%$ & \\
\hline $\begin{array}{l}\text { I feel that I may be at higher than average } \\
\text { risk of serious illness associated with } \\
\text { COVID- } 19\end{array}$ & $\mathrm{n}=212$ & $\mathrm{n}=65$ & $\mathrm{n}=141$ & \\
\hline Strongly agree or agree & $17.5 \%$ & $40.0 \%$ & $43.3 \%$ & $\mathrm{p}<.001$ \\
\hline Neutral, disagree, or strongly disagree & $82.5 \%$ & $60.0 \%$ & $56.7 \%$ & \\
\hline $\begin{array}{l}\text { I prefer not to wear face masks while } \\
\text { indoors or during face-to-face lectures }\end{array}$ & $\mathrm{n}=212$ & $\mathrm{n}=49$ & $n=39$ & \\
\hline Strongly agree or agree & $16.5 \%$ & $6.1 \%$ & $7.7 \%$ & $\mathrm{p}=.082$ \\
\hline Neutral, disagree, or strongly disagree & $83.5 \%$ & $93.9 \%$ & $92.3 \%$ & \\
\hline $\begin{array}{l}\text { I am apprehensive about being on campus } \\
\text { in the fall }\end{array}$ & $\mathrm{n}=212$ & $\mathrm{n}=65$ & $n=140$ & \\
\hline Strongly agree or agree & $48.6 \%$ & $64.6 \%$ & $69.3 \%$ & $\mathrm{p}<.001$ \\
\hline Neutral, disagree, or strongly disagree & $51.4 \%$ & $35.4 \%$ & $30.7 \%$ & \\
\hline $\begin{array}{l}\text { I am not particularly worried about acquiring } \\
\text { the COVID-19 infection after returning to } \\
\text { campus }\end{array}$ & $\mathrm{n}=212$ & $\mathrm{n}=65$ & $n=140$ & \\
\hline Strongly agree or agree & $21.2 \%$ & $21.5 \%$ & $19.3 \%$ & $\mathrm{p}=.89$ \\
\hline Neutral, disagree, or strongly disagree & $78.8 \%$ & $78.5 \%$ & $80.7 \%$ & \\
\hline $\begin{array}{l}\text { I am comfortable with a requirement that } \\
\text { students and faculty wear masks in indoor } \\
\text { spaces and during classes. (EpiBios and }\end{array}$ & & $\mathrm{n}=30$ & $n=109$ & \\
\hline
\end{tabular}


medRxiv preprint doi: https://doi.org/10.1101/2020.07.15.20154682; this version posted July 16, 2020. The copyright holder for this preprint (which was not certified by peer review) is the author/funder, who has granted medRxiv a license to display the preprint in perpetuity.

\begin{tabular}{|c|c|c|c|c|}
\hline COE only) & & & & \\
\hline Strongly agree or agree & & $70.0 \%$ & $87.2 \%$ & $\mathrm{p}=.025$ \\
\hline Neutral, disagree, or strongly disagree & & $30.0 \%$ & $12.8 \%$ & \\
\hline $\begin{array}{l}\text { Strongly encouraging students to wear } \\
\text { masks while indoors or during face-to-face } \\
\text { lectures is a good idea }\end{array}$ & $n=212$ & $\mathrm{n}=35$ & $\mathrm{n}=32$ & \\
\hline Strongly agree or agree & $85.8 \%$ & $91.4 \%$ & $96.9 \%$ & $\mathrm{p}=.161$ \\
\hline Neutral, disagree, or strongly disagree & $14.2 \%$ & $8.6 \%$ & $3.1 \%$ & \\
\hline $\begin{array}{l}\text { I would prefer to have all lectures and } \\
\text { classwork online this fall }\end{array}$ & $\mathrm{n}=212$ & $\mathrm{n}=35$ & $\mathrm{n}=32$ & \\
\hline Strongly agree or agree & $20.8 \%$ & $44.6 \%$ & $66.7 \%$ & $\mathrm{p}<.001$ \\
\hline Neutral, disagree, or strongly disagree & $79.2 \%$ & $55.4 \%$ & $33.3 \%$ & \\
\hline $\begin{array}{l}\text { I prefer to be in the classroom as much as } \\
\text { possible this fall }\end{array}$ & $n=211$ & $\mathrm{n}=65$ & $\mathrm{n}=141$ & \\
\hline Strongly agree or agree & $74.5 \%$ & $67.7 \%$ & $59.2 \%$ & $\mathrm{p}<.001$ \\
\hline Neutral, disagree, or strongly disagree & $25.5 \%$ & $32.3 \%$ & $40.8 \%$ & \\
\hline $\begin{array}{l}\text { I am concerned about my ability to conduct } \\
\text { research in the fall }\end{array}$ & $n=212$ & $\mathrm{n}=49$ & $\mathrm{n}=38$ & \\
\hline Strongly agree or agree & $35.9 \%$ & $36.7 \%$ & $36.8 \%$ & $\mathrm{p}=.988$ \\
\hline Neutral, disagree, or strongly disagree & $64.1 \%$ & $63.3 \%$ & $63.2 \%$ & \\
\hline $\begin{array}{l}\text { I am concerned about maintaining good } \\
\text { progress towards my degree }\end{array}$ & $\mathrm{n}=212$ & $\mathrm{n}=49$ & $\mathrm{n}=39$ & \\
\hline Strongly agree or agree & $52.4 \%$ & $63.3 \%$ & $43.6 \%$ & $\mathrm{p}=.174$ \\
\hline Neutral, disagree, or strongly disagree & $47.6 \%$ & $36.7 \%$ & $56.4 \%$ & \\
\hline
\end{tabular}

